Saint Louis University School of Law

Scholarship Commons

All Faculty Scholarship

2001

\title{
Questions of Fact and Law in Russian Jury Trials: The Practice of the Cassational Courts Under the Jury Laws of 1864 and 1993
}

Stephen C. Thaman

Saint Louis University School of Law

Follow this and additional works at: https://scholarship.law.slu.edu/faculty

Part of the Comparative and Foreign Law Commons

\section{Recommended Citation}

Thaman, Stephen C., Questions of Fact and Law in Russian Jury Trials: The Practice of the Cassational Courts Under the Jury Laws of 1864 and 1993 (2001). Revue internationale de droit penal, 2001. vol. 72, p. 415-450.

This Article is brought to you for free and open access by Scholarship Commons. It has been accepted for inclusion in All Faculty Scholarship by an authorized administrator of Scholarship Commons. For more information, please contact erika.cohn@slu.edu, ingah.daviscrawford@slu.edu. 


\title{
QUESTIONS OF FACT AND LAW IN RUSSIAN JURY TRIALS: THE PRACTICE OF THE CASSATIONAL COURTS UNDER THE JURY LAWS OF 1864 AND 1993
}

\author{
Stephen C. THAMAN*
}

\section{Introductory Musings}

The recent reintroduction of trial by jury in criminal cases in Russia (1993) and Spain (1995), and the introduction of the jury for the first time in Venezuela (1998), constitutes a surprising reversal in a long-term trend towards elimination of the classic jury in favor of courts composed either exclusively of professional judges, or of so-called Amixed courts, @ in which professional judges and lay assessors collegially decide all questions of fact, law and sentence. In both new systems, an old dispute as to whether juries would merely be factitiders, or whether they would, as is the case in England and the United States, also apply the law to the facts, has been rekindled.

Most likely neither the primitive Norman-English juries, ${ }^{1}$ nor Germanic scabini or rachimburgen, ${ }^{2}$ nor the ancient Scandinavian lay courts ${ }^{3}$ worried about the separation of questions of fact and law. Self-informing juries were definitely masters over the "acts" and thus masters over the fate of the accused-whether he or she would remain a part of the community, be banished, be subject to a wergild or a fine. Those primitive popular courts were probably concerned mainly with the social function of law, with resolving a dispute and restoring the peace of the community. Separation of fact and law was likely not important for them. Only with the intervention of the judge, with a division of labor among two classes of....

* Associate Prolessor, St. Louis University School of Law.

1. For histories of early juries in Britain, see: WILLIAM FORSYTH. TRIAL BY JURY. (1878). Reprinted (1971), at 48 et seq;; JOHN PHILLIP DAWSON. A HISTORY OF LAY JUDGES (1960), at 118-128.

2. See JOHN P. RICHERT. WEST GERMAN LAY JUDGES (1983), at 48-53; Forsyth, supra note 1 , at 94-102.

3. For a classic study of these ancient institutions see, THORL. GUOM. REPP, A HISTORICAL TREATISE ON TRIAL BY JURY, WAGER OF LAW, AND OTHER CO-ORDINATE FORENSIC INSTITUTIONS FORMERLY IN USE IN SCANDINAVIA AND ICELAND (1832); cf. Forsyth, supra note 1, at 6.57, for a comprehensive view of the old juries. 
decisionmakers, did it become necessary to differentiate their functions. ${ }^{4}$ And with the intervention of the judge, came the politicization of criminal law, its centralization, and subjugation to the metropolitan power, indeed, its scientization. The judges, representing the King, became the repositories of the law, in essence, enabling them to control and direct the decentralized decisionmakers, the jury.

On the European Continent the old customary decisionmaking bodies were displaced by judges, representing the dual central powers of the monarchy and the church. Unlike English common law judges, whose legal precedents incorporated customary law to a large extent, continental judges were more like priests, whose duty to find the truth had religious undertones, even when they were royal, rather than ecclesiastical judges. Law became a science of ascertaining the truth, something only specialists could do-i.e., judges, not lay persons. Tendencies in this direction were evident in England in the $17^{\text {th }}$ and $18^{\text {th }}$ Centuries when Crown judges, confronted with religious and political dissidents and their allegedly seditious publications, tried to restrict juries to merely finding whether the writing in question was $\forall$ published," leaving to the judge the $\forall$ legal" questions of whether the writing was seditious. The vigorous reaction to this attempt by the judiciary to curb the power of the jury was the proclamation of the right to jury nullification. The push for so-called powers of "nullification $\forall$ subsided following the passage of a a new libel law which restored the power of the jury. ${ }^{5}$ The monopolization of the law-finding tradition by judges succeeded, however, on the European continent, where the judge-driven secret, written inquisitorial system replaced the customary courts lock, stock and barrel.

This "politicization" of criminal procedure, its transformation into a matter of official, state concern, paralleled the replacement of the adversary system by the system of oficial state prosecution, dominated by a public prosecutor. ${ }^{6}$ No longer was the criminal law limited to crimes which resulted in concrete harm, crimes which could be seen with the naked eye, and proved by the testimony of lay eyewitnesses or with concrete victims who would bring their private prosecutions.

4. Repp saw the modem jury as a mixture of old Ajuries $\cong$ which were factfinders and investigators who pledged to find the truth and Awagers of law, $\cong$ usually a group of 12 Acompurgators $\approx$ gathered by the defendant to swear to his/her credibility. See Repp, supra, note 3 at 136 . He also points out the animosity toward the jury felt by judges, and expressed in at 136 . He also points out the animosity toward the jury felt by judges, and expressed in
junisprudence, and remarks: ABut juries are, I would not say, popular, but a purely republican institution, the first fruit of liberty, and its last survivor. Public opinion supports it, and maintain it, Beven though lawyers smile, Bthough kings may frown. $\equiv 1$ d. at 104 .

5. Thomas A. Green The English Criminal Trial Jury and the Law-Finding Traditions on the Eve of the French Revolution in ANTONIO PADOA SCHLPPA. (Ed.) THE TRIAL JURY IN ENGLAND, FranCE, Eve of the French Revolution in ANTONIOP P
GERMANY. 1700-1900 (1987), at 41, 57-68.

6. See Thomas Weigend. DelikTSOPFer und StrafVerfahren (1989), at 103-117, for an excellent description of this process in Germany.
The State and the Church invented crimes against the state or religion and used this pretext to invent the inquisitorial system, in which the state, as victim, prosecuted the case. ${ }^{7}$ Later the state claimed it was a victim even in those cases in which their was a concrete result and pre-empted private prosecutions even in those areas, pushing the victim completely out of the criminal trial. ${ }^{8}$ These new crimes which could not be seen or testified to required new kinds of judgesimbued in the science (or was it witchcraft?) of the law. The procedure had to be secret--these crimes could neither be seen nor heard by normal persons. These metaphysical roots of the inquisitorial system were revealed again during the reigns of terror in the Soviet Union in the 1920's and 30's and in other so-called socialist countries. It seems as if modern $\forall$ victimless crimes" have also been a vehicle by which the state has wrested the administration of justice from community control. The Federal anti-drug campaign's use of grand jơtitiss and the protection of the secrecy of undercover informers all show the continued vigor of this type of law enforcement.

At any rate, as law continued its pretensions to becoming a science, it collided with the archaic presence of the jury, especially in Continental Europe, where this old customary institution was perceived as a bulwark of democracy and $a$ tool in the revolutions against absolute monarchy. Once juries were introduced, first in France, and then, gradualiy, in most Continental European countries, the division of labor between the entrenched professional (royal) judges, and the new juries had to be articulated. Many preferred the pure English model, in which the jury decided guilt and the judge imposed sentence. But others did not want to abandon their fledgling Rechtswissenschaft and leave the imputation of guilt alone to unindoctrinated laypersons. This doctrinal dispute was a mask for a real political dispute. Would the centralized judicial institutions (and indirectly the monarchy) maintain their control over the administration of justice or would the upstart bourgeoisie (for nearly all early jurors had to be property owners, educated, etc. with the right to vote) assert its power as jurors?

Sir Edward Coke as early as 1620 proclaimed "Ad quaestionem facti non respondent judices; ad quaestionem juris non respondent juratores," but juries in England by and large were recognized, not only as judges of the facts, but also as judges of guilt, by virtue of their ability to apply the law, delivered by the judge in instructions, to those facts.

7. A. Esmein. A History of Continental Criminal Procedure with SPECial ReFerence to FRANCE (1913), at 10-11 (note 2), notes that inquisitorial procedure was first used in heresy cases and later extended to other normal crimes.

8. In consolidating its power, the state also took upon itself the task of Asecuring the peace. $=$ The advent in the late Middle Ages of organized criminality in the form of Ahighwaymen $\cong$ as well as the necessity to supress blood revenge provided also legitimate bases for state assumption of criminal prosecution. Weigend, supra, note 6, at 61-64. 
The degree to which juries should apply the law, however, was the subject of controversy throughout the 19th Century in the wake of Continental Europe's importation of the Anglo-Saxon jury following the French Revolution. By and large, Continental European countries, and among them Russia, rejected the division of labor between judge and jury favored in England and America, according to which the jury returns a perfunctory verdict of "guilty" or "not guilty," following instructions by the court as to the law which must be applied in determining guilt with respect to each charged offense, and which principles of criminal procedure govern the weighing and evaluation of the evidence received. Continental Europeans adopted a type of "special verdict $\forall$ composed of an often long and complicated list of questions relating to the acts allegedly committed by the defendant, the intent with which the acts were commilted, any circumstances which justified, excused, mitigated or aggravated the commission of the acts, and finally, in most jurisdictions, relating to guilt.

But that was not the end of it. Many European jurists did not feel lay people could or should "apply the law" to the facts they found to be true, but should leave that to the Bench, legally trained (as many English and American judges were not) and imbued with the duty to seek the truth and ensure the equal application of the law according to the rules of legal "science." The French, following Montesequieu, believed that the jury should only determine the "facts" and the Bench should be responsible for applying the law to the facts found true by the jury and thus decide guilt, not to speak of punishment. But the English tradition of the jury as the "conscience" of the community, deciding cases according to its "conscience" (in French, intime conviction) and "commonsense" and informed by the moral values of the community made it ideologically difficult to restrict the jury to the mere determination of "naked facts. $\forall$ Thus, most legislations allowed the jury to decide the question of "guilt," yet still attempted to protect the Bench's monopoly in applying the law. The difficulty in separating "questions of fact" from "questions of law" and thus delimiting the provinces of jury and judge has long been recognized in the Continental European discussion:

"It is at the same time both clear and plausible that the historical component of the factual question relating to guilt or innocence cannot be separated from the legal, without turning the jury into a joke, which is different from other jokes only because it is too serious a thing to be laughed at. For if the jury is only asked whether certain facts laid before them are historically true or not, then the judges, appointed by the overlord, are alone lords and masters over the guilt or innocence of the accused, for the qualification of the deed always depends on their judgment." ${ }^{\text {g }}$

9. ANSELM FEUERBACH. BETRACHTUNGEN ÜBER DAS GESCHWORENEN-GERICHT (1813), at 170 (author $=\mathbf{s}$ translation).
The inability to separate questions of fact and law, and the European unwillingness to adopt the Anglo-American verdict form, which allows the jury to apply (and even nullify) the law in the secrecy of their deliberations, gradually led to the consolidation of jury and Bench in the European "mixed courts" 10 in which however, the division of labor between lay and professional judges, and the precise manner of instruction as to the law and its application are also cloaked in the absolute secrecy of their deliberations. The classic separation of powers within the adversarial criminal process between a neutral judge, responsible for deciding questions of law and punishment, and a panel of non-legally-trained lay: persons responsible for questions of fact and guilt, gave rise to the principle of "free evaluation of the evidence" unfettered by formal rules of evidence. ${ }^{11}$ Important developments in the substantive criminal law which affect the presentation and evaluation of evidence such as the separation of factual from legal questions and the breaking-down of criminal offenses into theil various constitutive elements, both objective and subjective, arguably have their roots in the need for the judge to instruct the jury on how to apply the law to the facts of the case. ${ }^{12}$ But even more fundamentally, it was the "pious perjury" of early jurjess who would reinterpret the facts of cases before them to fit them in to the official doctrine on issues such as self-defense or murder which greatly affected the development of Common Law substantive criminal law. ${ }^{13}$

Even in the $19^{\text {th }}$ Century, Continental Europeans, while introducing progressive procedural safeguards for the criminal defendant, such as the presumption of innocence, oral, public and increasingly adversary trials, etc., did not warm to the classic jury, as they treated it as being alien to certain other principles of the inquisitorial criminal process: (I) the duty of the State (prosecutor; judge, investigating judge) to ascertain the truth; (2) the necessity of reviewability of judgments, as reflected in the requirement of giving reasons for findings of guilt

10. See Peter Landau. Schwurgerichte und Schöffengerichte in Deutschland im 19. Jahrhundert bis 1870, in Schioppa, supra, note 5, at 303. For an excellent summary of the 19th Century German discussion, see HUGO MEYER. THAT- UND RECHTSFRAGE IM GESCHWORENENGERICHT, INSBESONDERE IN DER FRAGESTELLUNG AN DIE GESCHWORENEN (1860).

11. John Langbein sees the seeds of "free evaluation of evidence" being planted in Continental Europe before the introduction of trial by jury with the weakening of the institution of torture and the rise of poena extraordinaria. JOHN H. LANGBEN. TORTURE AND THE LAW OF PROOF (1977), at 59. On the transformation of the Aromantic notion $\cong$ of intime conviction into the Aless expansive $\cong$ notion of freie Beweiswürdigung, which still required adherence to Aextralegal canons of valid inference, $\cong$ see MiRJAN R. DAMASKA. EVIDENCE LAW ADRIFT (1997), at 22.

12. See Ennio Amodio Giustizia popolare, garantismo e partecipazione in ENNIO AMODiO (ed.) I GIUDICE SENZA TOGA. ESPERIENZE E PROSPETTIVE DELLA PARTECIPAZIONE POPOLARE AI GIUDIZI PENALI (1979), at 13 (note 30)

13. See thomas A. Green. Verdict According to Conscience. Perspectives on the ENGLISH CRIMINAL TRIAL JURY, 1200-1800 (1985), at 65-102. 
or innocence; 14 and $(3)$ the principle of mandatory prosecution ( $\forall$ legality principle $\forall$ ), which is antipathetic to the unbridled $\forall$ discretion" of juries to acquit out of sympathy or nullify the harshness of the sentence. ${ }^{15}$ They opted for a form of lay participation more conducive to the adherence to the aforementioned principles: the "mixed court" of professional judges and lay assessors, collectively responsible for all questions of law, fact, guilt and sentence.

As was the case in the $19^{\text {th }}$ Century, the age-old controversy surrounding the separation of questions of law and fact has raised its head in Russia, following the 1993 return to trial by jury, albeit in only 9 of the 89 constituent parts of the republiç. Unfortunately, the response to this issue of the judicial body with the main responsibility for interpreting the Jury Lawit, the Supreme Court of the Russian Federation, and, particularly, its Cassational Panel, has, in the author $=\mathrm{s}$ opinion, been arbitrary, superficial and wrongheaded. This article will compare the approach of the modern Supreme Court and its Cassational Panel to that of the pre-revolutionary Cassational Senate which decided similar issues in relation to the Jury Laws of 1864.

\section{The General Structure of the Question Lists}

Both before and after the October Revolution, the Russian legislators rejected the Anglo-American general verdict of "guilty" or "not-guilty," in favor of a list of questions or propositions, following the French model, which was adopted by moșt Continental European countries in the $19^{\text {th }}$ Century. Yet as will be apparent from the language of the two statutes, both legislators equivocated as to whether they actually wished to limit the jury to deciding mere "naked historical facts" by allowing the jury to make a finding of $\forall$ guilt" or lack thereof as to each charged offense.

The Russian Jury Law of 1993 requires that three basic questions be asked with respect to each crime charged by the public prosecutor: (1) has it been

14. According to Amodio, supra, note 12 , at $46-48$, Art III (I) of the Italian Constitution requiring reasons to be given for all judicial decisions, makes the reintroduction of the classic jury impossible.

15. On jury nullification in the United States, see Albert W. Alschuler \&Andrew G. Deiss, A Brief History of the Criminal Jury in the United States, 61 U. CHICAGO. L. REv. 867, 871-875 (1994)

16. For a detailed history of the passage of the new lay and an analysis of the law and its implemenlation in the first year of its functioning, see Stephen C. Thaman. The Resurrection of Trial by Jury in Russia, 31 STAN. J. INT=L Law 61-274 (1995) (hereafter, Thaman, Resurrection).

17. Zakon Rossiyskoy Federatsii o vnesenii izmeneniy $i$ dopolneniy $\vee$ Zakon RSFSR o sudoustroystve RSFSR, Ugolovno-protsessual=nyy kodeks RSFSR, Ugolovnyy kodeks RSFSR Kodeks RSFSR ob administrativnykh pravonarusheniiakh. VEDOMOSTI $S \Rightarrow>$ EZDA NARODNYCH DEPUTATOV ROSSIYSKOY FEDERATSII I VERKHOVNOGO SOVETA ROSSIYSKOY FEDERATSII. No. 33, 1313, 2238-2264 (Aug. 19, 1993). proved, that the charged offense was committed; (2) has it been proved, that the offense was committed by the defendant; and (3) is the defendant guilty of having committed the offense. The court may also pose only "one basic question as to the guilt of the defendant representing a consolidation of the three basic questions." 18

The 1993 law follows the same basic structure of questions lists under the Jury Law of 186419 :

"Questions as to whether the criminal acts were committed, whether they were the acts of the defendant and whether guilt therefor should be imputed to him, are united into one collective question as to the guilt of the defendant, if no doubt has arisen as to whether the criminal acts were committed, nor as to whether guilt therefor should be imputed to the defendant if they were found to be his acts. In the case of any doubt as to any of the questions they should be posed separately."20

After the trifurcated quilt question (which in both regimes may be united into one question), both the laws of 1993 and 1864 provide for subsidiary questions relating to facts which modify guilt.

"After the principal question of the defendant=s guilt particular questions are posed as to those circumstances which aggravate or mitigate the level of guilt, or modify its character or lead to the exoneration of the defendant from responsibility." ${ }^{11}$

Again, the modern jury law follows the language of the 1864 provisions:

"After the principal questionBis the defendant guilty of the criminal act, which is the object of the accusatory pleading,-, separate questions are asked as to those circumstances, which especially increase or decrease the level of guilt. As to circumstances which only influence the imposition of punishment for the same level of crime questions are not posed."22

Finally, the 1993 law removes certain questions from the purview of the jury which involve "juridical qualification" of facts, using the following formulation:

18. $\rightarrow 449$ Ugolovno-protessual=nyy kodeks RSFSR (hereafter UPK RSFSR), all citations from the Criminal Procedure Code of the RSFSR are translated by the author from the Russian in SBORNIK KODEKSOV ROSSIYSKOY FEDERATSII (BOOK 2) (1999), at 150-343.

19. All citations from the Ustav ugolovnogo sudoproizvodstva (November 20, 1864), recently published in SUDOUSTROYSTVO I UGOLOVNYY PROTSESS ROSSII. 1864 GOD. SBORNIK NORMATIVNYKH AKTOV (1997) (hereafter UUS), at 73-238 (all translations by the author).

20. $\rightarrow 754$ UUS, supra, note 19 , at $168-69$.

21. $\rightarrow$ 449(para.2) UPK RSFSR.

22. $\rightarrow 755$ UUS, supra note 19 , at 169 . 
"Questions requiring of the jurors the juridical qualification of the status of the defendant (as to his prior convictions, as to the fact he has been declared to be an especially dangerous recidivist, as to the duties of his official position) or also other questions requiring strict juridical evaluation in the juryzs rendering of the verdict, may not be posed, neither separately, nor as part of other questions. ${ }^{23}$

In its Opinion No. 9 of December 20,1994, the Supreme Court of the Russian Federation (SCRF) interpreted the language italicized above to eliminate from the question list (i.e. from the jury 3 s verdict)

"the use of such juridical terms as intentional or negligent murder, intentional murder with exceptional cruelty, intentional murder with hooliganistic motivation or for personal gain, intentional murder committed in the heat of passion, murder using excessive force in self-defense, rape, robbery, etc,"24.

As we shall see, the decisions of the Cassational Panel and the Plenary Session of the SCRF have used this arbitrary interpretation of the above language to effectively reduce the Russian jury to judges of $\forall$ naked historical facts" and even "naked historical actus reus" insamuch as they have interpreted criminal intent or mens rea a critical element of all criminal offenses (and especially intent or mens rea a critical element of all criminal jusies) as being a question of law for the professional judges to answer.

We will now attempt to analyze why the decisions of the SCRF are wrong in this respect, how they contradict the plain meaning of the law, and how they appear to be pragmatically aimed at reversing acquittals in the "ifight against crime."

\section{What does the Jury's Finding of Guilt Actually Entail?}

The jury in English and American cases is really a $\forall$ procedural Sphinx"25, inasmuch as its laconic "guilty" or $\forall$ not-guilty" reveals none of the logic or thought-processes which led to the verdict. At most when the jury in a murder case finds the defendant guilty of a lesser-included offense of, say, involuntary case finds the defendant guily of a lessound that the defendant had no intent to

23. $\rightarrow 449$ (para,3) UPK RSFSR.

24. Postanovlenie Plenuma Verkhovnogo Suda Rossiyskoy Federatsii: AO nekotorykh oprosakh primeneniia sudami ugolovno-protsessual=nykh norm, reglamentiruiushch hikh proizvodstvo vopula SBORNIK POSTANOVLENIY PLENUMOV VERKHOVNYKH SUDOV SSSR I RSFSR (ROSSIYSKOY FEDERATSII) PO UGOLOVNYM DELAM (1995), at 569-580.

25. Damaska, supra, note 11, at 44. kill, a necessary element of most murders. In Continental European trials $\forall(\mathrm{t})$ he trial judge is obligated in a written opinion to make clear not only what items of evidence support each finding and what chains of inference lead from these items to specific factual determinations." ${ }^{26}$ Russian criminal judgments must be reasoned ${ }^{27}$ as is the case in most Continental European countries and special verdicts in the form of "question lists" were introduced in France, and followed in European jury systems in the $19^{\text {th }}$ Century for this reason. The three-pronged guilt question in both the old and the new Russian legisiations allows the sentencing judge to know, in the case of an acquittal, whether the jury found that the corpus delicti of the charged offense was simply not proved, whether they had doubts as to the defendant's authorship of the crime, or whether guitt could not be assigned due to an excuse (such as duress or insanity), a justification (such as self-defense) or due to some other reason. ${ }^{29}$

Since the nature of the questions as to corpus delicti (was a crime committed?) and authorship (was it the defendant who committed it?) are rather straightforward, it is important to focus on the nature of the guilt question, the third and crucial component of the principal question in the jury's verdict. This analysis will deal with the following issues: (1) How is the guilt part of the three-pronged question different than the proof of the material elements of corpus delicti and authorship (putting aside, for the time being, the question of jury nullification)? (2) How should questions relating to mitigating or exculpatory evidence be phrased in relation to the guilt question? (3) To what extent are aggravating and mitigating circumstances and mental state questions of fact for the jury, or of law, for the judge? (4) Did the Russian legislators intend to give the jury the power to nullify" the law and vote for guilt, despite the proof of corpus delicti and authorship?

\section{A. How does the jury determine "guilt" of the criminal acts found to be proved?}

In the majority of the cases heard in the first year of modern Russian jury trials, the court has asked the three basic questions as to each charged offense. I analyzed the question lists from 80 cases of murder or attempled murder. In 59 of these all three questions were asked. ${ }^{29}$

Famous pre-revolutionary judge and theorist A.F. Koni supported a move to the simple English verdict form in which the jury votes guilty or not-guilty without

26. Id. at 45.

27. See $э 3314.1,462$ UPK RSFSR.

28. The problem of acquittals on non-legal or meta-legal grounds, so-called jury nullification, will be discussed, infra.

29. Thaman, Resurrection, supra note 16 , at 115 
being submitted any list of specific questions, ${ }^{30}$ and it will be noted from the language of $э 754$ UUS, supra, that the old Russian jury law favored uniting the three elements of the guilt question into one.

The SCRF, however, has indicated a preference for the formulation of all three questions and insists that if the court formulates just one question it must contain the elements of corpus delicti, perpetration and guilt. ${ }^{31}$ The SCRF reversed two aggravated murder judgments entered by a Rostov judge because he asked one simple question as to guilt, for instance: "Is Butakov guilty of murdering Aleshina with the complicity of Zimov on 27.5.93?" He then instructed the jury as to the applicable law. ${ }^{32}$

Judges are also not in agreement as to the amount of detail which must be included in the jury questions. Some hold that jurors must find virtually all of the factors to have been proved, which must be addressed in the descriptive part of the judgment. ${ }^{33}$ In the first cases under the new jury regime, this has lead to very complicated questions usually phrased precisely in the terms of the indictment including detail not crucial to the jurors' answering of the three fundamental questions which are their responsibility. Jurors have been asked to determine the exact number, type and seriousness of the wounds inflicted in homicide cases the exact number of items stolen in theft counts, the precise sequence of the defendant's acts, and statutory aggravating factors such as whether or not the defendant was drunk. ${ }^{34}$ The SCRF reversed an attempted murder conviction, holding one of the errors to have been the failure to include a question relating to whether or not the defendant was drunk if this was to be relied on as an aggravating factor. ${ }^{35}$

The SCRF has ruled that the court, in writing the judgment, may only refer to facts found to be true by the jury ${ }^{36}$ and has reversed several cases, including a

30. A.F.KONI, SOBRANIE SOCHINENII (1967). VOi. 4, at 273.

31. SCRF, Decision No. 9,317 , supra, note 24 .

32. Case of Butakov/Zimov (Rostov Regional Court) SCRF No. 41-kp-094-106sp(11.28.94); cf. Case of Stoianenko/Shishkov (Rostov Regional Court) SCRF No. 41-k0-094-108sp (11.22.94).

33. ээ 462, 314(para. |) UPK RSFSR.

34. Drunkenness was an aggravating factor per $\rightarrow 39(10)$ of the now superseded Ugolovnyy kodeks RSFSR (hereafter UK RSFSR) This factor has been eliminated from the new Russian Penal Code enacted in 1995 (hereafter UK RF)

35. Case of Sogokon' (Moscow Regional Court) SCRF No. 4-kp-094-143sp (12.13.94). The SCRF also reversed acquittals in cases in which the question list did not reflect certain facts alleged in the accusatory pleading though there is no indication that the prosecutor objected to the formulations. Case of AbdullovTimosia/Kogtev (Ll=ianovsk Regional Court) SCRF No. 80-kp-098-35sp (7.30.98) Case of Volodin'Kotenko (Saratov Regicnal Court) SCRF No. 32-kp-098-53sp (10.22.98).

36. SCRF Dec. No. 9, +24, supra, note 24 death sentence, for failing to do so.37 The pre-revolutionary Cassational Senate also required the questions to include all facts in the lengthy indictments which could be relevant to guilt and sentence. ${ }^{38}$ Courts in Russia have presented this factual abundance, either in the form of a great number of separate questions relating to the various allegations in the indictment, or in long complex questions which restate the indictment. Either way, A.F. Koni accused the courts of trying to bury jurors in a morass of concrete facts in which essential and non-essential were indistinguishable. ${ }^{39}$ Excessive detail relating to historical facts not directly related to the elements of the offense complicates the jury's decisionmaking process, for a majority may agree as to some of the facts and not as to others. 40

Regarding the first approach, Selitrennikov cautioned against chopping up questions into myriad chunks, for it allowed the jury to find guilt as to an act which did not constitute a criminal offense. ${ }^{41}$ Foynitskiy felt that the courtsingaged in

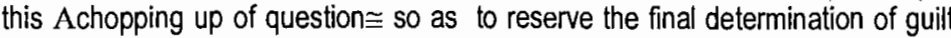
unto themselves. ${ }^{42}$ in the modern Russian jury trials the amount of questions has sometimes been staggering. 19 questions were asked relating to one count of murder in which the aggravating factor, the defendant's recidivist status, wass no even before the jury and other multiple-count, multiple-defendant cases in 1994 have had 41,52 and 87 questions asked the jurors. ${ }^{43}$ The question list in a case heard in Stavropol Territory in 1998 contained the incredible sum of 1,047 questions. ${ }^{44}$

The approach of other courts consisting in presenting virtually the entire tex of the indictment to the jury for affirmation or rejection could be condemned as

37. Case of Brovkin/Minkin (Stavropol Teritonial Coust) SCRF No.19-kp-094-42sk sp (12.13.94): see also Case of Gokorian/Artiunian (Stavropol Teritonial Court) SCRF No.19-kp-094-81sp (12.26.94) and Case of Sogokon (note 35, supra).

38. M. SELITRENNIKOV. O POSTANOVKE VOPROSOV NA SUOE UGCLOVNOM, PO RESHENIIAM KASSATSIONNOGO SENATA (1875), at 14. This was so Athat the judgment of the court can be based in an exact and positive sense on the decision of the jury, with no supplementation, expansion or limitaion of this decision on the part of the courtisef in Comente the jury to decide all factors which could aggravate the sentence with the current trend to redefine factors as sentencing elements for the judge, which the United States Supreme Court has recently stemmed a bit in the case of Jones v. United States, 526 U.S. 227 (1999).

39. Koni, supra note 30, Vol. 4 , at 273

40. A..(I)n the entire dense woods of concrete facts, often supplemented by questions posed by the jurors, it is not difficult to get lost.: Selitrennikov, supra note 38 , at 72 .

41. Id. at 71.72 .

42. I.YA. FOYNITSKIY. KURS UGOLOVNOGO SUDOPROIZNODSTVA. VOl. I. (1912), at 386-387.

43. Thaman, Resurrection, supra note 16, at 116-117.

44. Conversation with V.P. Stepalin, Judge of the Cassational Panel of the SCRF, 8.20 .98 , in Moscow. 
"leading" the jurors to rubberstamp the prosecution's theory, which will then be reiterated in the judgment. 45 Pre-revolutionary theorists felt that the Russian indictment, with its excess of detail often led to acquittals when incorporated verbatim into jury question lists due to lack of proof of collateral matters therein. This would be avoided with simple English indictments. ${ }^{46}$ Bobrishchev-Pushkin criticized the Amulti-layered and difficult-to-understand questions $\cong$ which he attributed also to the outdated criminal code and the "casuistic jurisprudence of the Cassational Senate. $\forall^{47}$ An example of a flawed question presenting a multitude of facts, some of which could be affirmed and others negated, comes from the trial of the accused murderer of Prince Arenberg in St. Petersburg:

"Is the defendant guilty of the fact, that, having conspired with another to steal property from Prince Arenberg, he went with this other person to his apartment, and, not being able to take all that they wanted, waited for Prince Arenberg to return home, hid in his bedroom, and when Prince Arenberg fell asleep, he was awakened by noise in his room, and according to a preconceived plan under such conditions, tied him and gagged his mouth and threw themselves on him, strangling him, broke the bone in his throat and held his mouth and nose, causing his death, and, departing from the apartment of Prince Arenberg, took part of the property which belonged to him?"48

The acquittal of two defendants for robbery-murder was recently reversed because the corpus delicti question left out elements of the charged act ${ }^{49}$ and the .

45 , In a study of the first year of jury trials under the new Spanish law, the author has noted how the old tradition of inquisitorial written proceedings curiously rears its head in the form of a

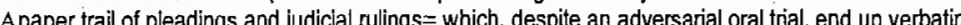
in the question list and the corts Jury, 21 HASTINGS INT'L \& COMP. L. REV. 241, 322-323 (1998) (hereafter, Thaman, Spain). In relation to question lists in the first year of the new Russian law, see Stephen Thaman, Postanovka voprosov pered kollegiey prisiazhnykh. . ROSSIYSKAIA YUSTITSIIA. Vol. 10, 1995, 8, at 9

46. BOBRISHCHEV-PUSHKIN. EMPIRICHESKIE ZAKONY DEIATEL'NOSTI RUSSKOGO SUDA PRISIAZHNYKH (1896), at 348-349.

47. 1 d. at 542.

48. Selitrennikov, supra note 38 at 73 , quoting from Decision $454 / 1870$ of the Cassationa Senate, and criticizing the question for uniting facts as to two crimes, burglary and murder, along with the aggravating circumstance of a preliminary conspiracy, into one question.

49. AAmong other things, the formulation of the first question-has it been proved that on May 11, 1997 in the forest strip Fevralev died of a knife wound and his automobile was stolen= does not contain all substantive circumstances of the act for which the convicted persons were charged AThus, in this question it was not mentioned that Fevaler was taken by force while being charged. AThus, in this question itwa no threatened with a knife to his throat, to the forest strip where he was killed, where he was administered four slash and puncture wounds to the chest and stomach, and that, after he died from the knife wounds to the throat, his body was taken deep into the strip and hidden, and that his car
Cassational Panel of the SCRF rejected the trial court's decision to include all of these details in the second question as to authorship, $\forall$ where it should only have been a question of whether it had been proved that the accused committed the act, all factual circumstances in the dossier-in substance-transcribed verbatim from the resolutive part of the accusatory pleading $\forall$ were included. ${ }^{50}$

Foynitskiy stressed that questions should be restricted to facts relating to the legal elements of the charged offenses and should be phrased in understandable language, not in technical medico-legal jargon relating to wounds, etc. ${ }^{51}$ This has also been suggested by modern Russian scholars ${ }^{52}$ and has been followed by a minority of courts. ${ }^{53}$

\section{B. How Should Questions as to Excuses, Justification or Mitigating Circumstances be Phrased?}

The formulation of questions related to affirmative defenses or lesserincluded offenses raised problems in the first trials under the 1993 law. The Moscow and Ivanovo courts treated lesser homicides in the heat of passion, or using excessive force in self-defense ${ }^{54}$ as full-blown crimes with constituent elements which had to be proved by the jury just like the charged capital crimes. Question lists first addressed the basic three questions relevant to an intentional homicide, and then asked those questions relating to the elements of the lesser homicide offenses, or justifiable homicide in self-defense. Questions relating to defenses were formulated requiring positive proof that the victim committed an act upon which self-defense or heat of passion could be predicated, in the form of, "for instance: "has it been proved that the victim attacked the defendant?", etc. ${ }^{55}$ In

was stolen. $\cong$ (Case of DaudovNatsaev (Rostov-on-the-Don Regional Court), SCRF No. 41-kp-09838 sp (4.14.98), reversing jury verdict of 1.20 .98 )

50. ASuch a complicated question, formulated according to 3449 UPK RSFSR, caused an unclear answer by the juny: AYes, proved as to the factual circumstances connected with the theft of Fevralev's automobile $\equiv$ and $\forall$ No, not proved, that Daudov infilicted knife blows $\forall$ and $\forall$ No, no proved, that Vatsaev influenced Daudov in killing Fevralev. $\forall$ The court concluded: $\forall$ Thus, from the verdictBthe totality of the questions and-answersBit is impossible to determine what was done by each accused and as to the qualification of the act, and the protest in this instance must be affirmed. $\forall$ (Case of DaudovNatsaev, supra note 49).

51. I. YA. FOYNITSKIY. KURS UGOLOVNOGO SUDOPROIZVODSTVA. Vol. II. (1915), at 451.

52. I.B. Mikhaylovskaia in ALEKSEEVA, L.B. ET AL. SUO PRISIAZHNYKH. POSOBIE DLIA SUDEY (1994), at $96-97$.

53. Thaman, Resurrection, supra note 16, at 117.

54. $+\div$ 104, 105 UK RSFSR, now codified at $\S \S 107,109$ UK RF. All cites from UK RF taken from Ugolovnyy kodeks Rossiyskoy Federatsii, in SBORNIK KOOEKSOV ROSSIYSKOY FEDERATSII, supra note 18 , at $3-149$

55. Thaman, Resurrection, supra note 16 , at 118. 
the first Saratov cases, questions related to affirmative defenses were framed in the following manner: "/s it probable that the acts of Artur Martynov were carried out in self-defense?" This form was also used in relation to defenses of alibi, accident and heat of passion in later cases. If the jury answered in the affirmative, then the judge following the verdict qualified the crime as a lesser offense or an acquittal in the event of justifiable self-defense. ${ }^{56}$

Phrasing the question in terms of probability was initially considered to be more in conformity with the presumption of innocence and the prosecution's burden of proof57 but Saratov judges discontinued using this form in favor of the following phraseology: "Has it been established that Gavrilenko committed the violent act described in Question 5 because Chernov had earlier given him a beating?" ${ }^{58}$ The SCRF has ruled that questions should not be formulated in terms of probability ${ }^{59}$, in much the same way that the Cassational Senate did before the revolution. 60

The formulation of the guilt question has presented problems in the modern Russian jury trial as it had before the revolution. When the jury is asked to find a defendant guilty or not guilty of a violation of a certain section of the criminal code. as in the U.S., then no ambiguity is possible. Where, however, the jury is asked to determine whether a certain concatenation of facts charged in the indictment or adduced in court, has been proved, and whether the defendant is guilty thereof, problems arise, for the fact situation may neither fully include all the elements of the charged offense, nor negate possible affirmative defenses and thus no criminal guilt may ensue. ${ }^{61}$

Many of the first attempts to deal with affirmative defenses have been flawed because the courts formulated the guilt question in relation to a fact situation indicative of intentionai homicide in such a way that it precluded consideration of mitigating factors. In several Moscow trials, the jury had to answer in the negative the question as to whether the defendant intentionally killed the victim during a quarrel (i.e., without statutory aggravation) in order to even get to the defense questions. In one case this led to serious confusion of the jury. The jury found

56. Case of Martynov (Saratov Regional Court) Judgment of 12.17.93. See Thaman Resurrection, supra note 16, at 119 .

57. S.A. Pashin, in SUD PRISIAZHNYKH: NAUCHNO-PRAKTICHESKIY SBORNIK (1994), at 282

58. Case of Gavrilenko (Saratov Regional Court) Judgment 3.14.94. See Thaman, Resurrection, supra note 16 , at 119 .

59. SCRF, Dec. No. 9, э18, supra note 24

60. Selitrennikov, supra note 38 , at 1301

61. Because jurors were not asked as to guilt of a particular crime, the judge had to make sure that the question of guilt contained all the legal elements of the crime, so an affirmative answer would buttress a judgment of guilt as to the charged crime. V.N. PALAUSOV. POSTANOVKA VOPROSOV PRISIAZHNYM ZASEDATELLAM PO RUSSKOMU PRAVU (1885), at 84,87 . with a simple majority of seven votes to five that the defendant was guilty of intentionally killing the victim but found unanimously that the killing followed a quarrel. This foreclosed them from answering any of the eleven questions which dealt with self-defense, heat of passion or non-intentional homicide, though the testimony was uncontradicted that the victim had started a fight with the defendant and then lunged at him before he was stabbed. Despite the clear contradictoriness of the verdict, and the fact that the aggrieved wilfully violated the law in telling the jury of the defendant's prior criminal record, the SCRF still refused to reverse the conviction.62 Though it is clear that a person can intentionally kill another during a quarrel, yet be acquitted due to justifiable selfdefense or found guilty of lesser offenses of murder in the heat of passion or using excessive force in self-defense, the Supreme Court upheld an attempted murder conviction in a case in which the jury was precluded from rediching the self-defense issue if they found an intentional killing and defense counse specifically alleged this as reversible error. ${ }^{63}$. The pre-revolutionary Cassational Senate clearly ruled that posing self-defense questions in such a manner was reversible error. ${ }^{64}$ Judges in the first modern Saratov cases usually formulated the question of guilt in relation to the homicidal act, before (and without precluding) the questions relating to mental state and affirmative defenses. If the jury found the defendant guilty of the homicidal act, then, depending on the answers to the questions related to self-defense, heat of passion, etc., the judge would find the defendant guilty either of murder as charged, or lesser charges of murder in the heat of passion or using excessive force in self-defense.

Problems arose, however in a case in which the jury clearly wanted to acquit .. the defendant of murder on grounds that he acted in self-defense. The jury found the defendant "guilty" of stabbing the victim to death, but in subsequent questions found that the victim had previously acted "incorrectly" and that the acts were

62. Case of Bogatyrev (Moscow Regional Court) (Judgment of 1.25.94), affirmed, SCRF No, 4-kp-094-61sp (4.26.94). See Thaman, Resurrection, supra note 16, at 118, 175-176.

63. Case of Sokolov (Rostov Regional Court)(Judgment of 8.19.94), affimed, SCRF No. 41 . kp-094-124sp (12.26.94). See discussion in S.C. Thaman, The Jury as Catalyst for the Reform of Criminal Evidentiary Procedure in Continental Europe: the Cases of Russia and Spain in J.F. NisBoER \& J.M. REINTJES (ed.) PROCEEDINGS OF THE FIRST WORID CONFERENCE ON NEW TRENDS IN CRIMINAI Q J.M. REINTJ JES (ed.) PROCEEDINGS OF THE FIRST
INVESTIGATION AND EVIDENCE (1997), 393, at 397.

64. Selitrennikov, supra note 38 , at 263 , citing the Vartanov Case (1038/1871). Selitrennikov shows how the questions should have been phrased: (1) A Was the death of the forest warden of the Yerevan transit post Avdey Luk=ianov, caused by gunshot wound in the night of the $22^{\text {nd }}$ to the $23^{\text {rd }}$ of August, 1869 by Moses Vartanov, 36 years-old? (2) If it was, then has it been proved that the death of Luk'ianov was caused by the defendant Vartanov as a result of necessary self-defense to ward off of Luk'ianov was caused by the defendant Vartanov as a result of necessary self-defense to ward of
a dariger which threatened his life, in which there was no chance to tum to the local police for defense? (3) if not proved, is Vartanov guilty of the crime, described in the first question, committed by him, though without a preconceived intent, while irritated, but not accidentally, and knowing that he threatened the life of another? /d. at 264-5. 
justified and did not constitute excessive force. The jury unanimously answered the following question in the affirmative: "Were the actions of Chernov in the staircase correct, when he pushed V.V. Yefremov into his apartment and kept pushing him within the apartment?" When confronted with this clearly contradictory "guilty" verdict, the judge reformulated the question list, with the defense questions preceding and precluding the question of guilt if answered in the affirmative. The jury unanimously acquitted. The SCRF reversed the acquittal, holding that it was error to phrase the self-defense questions in relation to the conduct of the victim, and that the question of self-defense and excessive force are legal questions for the judge and not the jury. 65

The confusion in both statutes, which appear to require the jury answer the "guilt" question before dealing with lesser-included offenses or theories of excuse or justification, is in part responsible for the problems encountered both now and before the revolution in correctly positioning and formulating that question. The Cassational Panel of the SCRF has reversed at least one conviction, because the trial judge refused to instruct sua sponte as to a lesser-included offense supported by the evidence ${ }^{66}$ and has reversed acquittals, because the trial judge has refused lesser-included instructions requested by the public prosecutor. ${ }^{67}$

\section{Mental State and Aggravating Circumstances: Questions of Law or Fact?}

\section{a. The Dispute as to Separation of Questions of Law and Fact}

This brings us to the last and most important problem area, the question of division of labor between judge and jury in determination of the guilt question. The Russian Supreme Court=s pedantic interpretation of $\forall$ other questions requiring strict juridical evaluation in the jury's rendering of the verdict $\forall+449(4)$ UPK RSFSR) in Decision No. $9^{68}$ has signalled a return to the separation of powers between jury and court inherent in the French Code d'Instruction Criminelle of 1808 , in which, following Montesequieu, the jurors:

"provide answers not as to guilt of the defendant of the charged crimes, but as to separate factual elements, articulated by the presiding judge in his

65. Case of Yefremov (Saratov Regional Court) Judgment of 5.20.94). Reversed, SCRF No. 32-kp-094-30sp (7.28.94). Thaman, Resurrection, supra note 16, at 119-120.

66. A. Shurygin, Zashchita v sudoproizvodstve s uchastiem kollegll prisiazhnykh zasedateley. ROSSIYSKAIA YUSTITSIIA. Vol. 9 (1997), 5 , at 6.

67. Two such cases are Case of Tikunov (Rostov-on-the-Don Regional Court), SCRF No, 40kp-096-26sp (4.10.96) and Case of Baykov (Moscow Regional Court), SCRF No, 4-kp-097-25sp $(2.6 .97)$.

68. See supra text accompanying note 28 questions, from which not they, but the presiding judge reaches a conclusion as to the presence or absence of criminal guilt in the defendant's act." 69

This early theory, that the jury only answers questions of fact, and the judge then applies the law, was, according to the most prominent Russian jurists decisively rejected in the 1864 Russian Code and the 1871 German Code of Criminal Procedure:

A different theory, that of guilt and punishment was proposed to, and finally did take its place, according to which jurors decide the question of guilt in its full magnitude, from both the factual and legal perspective, and the judges apply the established punishment to the guilty person and decides those procedural questions which arise in the case. ${ }^{70}$

The prevailing view in pre-revolutionary Russian legal science beld that the jurors' decision on the question of guilt must encompass an application of the law to the facts found to be true and that the jury was properly seen as the judges of guilt and the professional judges as the determiner of sentence. In the words of Selitrennikov.

of the

"Statutory terms usually contain general legal norms, general elements of the crime, as to which concrete facts must be related, and asking jurors to decide such elements, we ask them to make a juridical evaluation of facts, the decision of a question of law."71

Although the pre-revolutionary Cassational Senate was bound by the language of the UUS that required the jury to determine guilt, it interpreted $э 760$ UUS, which required questions be formulated in language understandable to the jury, ${ }^{72}$ as prohibiting judges from using much of the statutory language of the Criminal Code. Among the words which could not be used in jury questions were: "attempt," "theft," "intent," "personal gain," "robbery, " "false denunciation, " "rape, " "embezzlement," "aiding and abetting", "complicity, " "incitement, " "main perpetrator, " etc. The replacement of such "juridical terms" with at times more

69. Foynitskiy, Vol. 2, supra note 51 , at 448 .

70. $1 d$,

71. Selitrennikov, supra note 38 , at 22, ef. in more detail at 18-33. See also Foynitskiy, Vol. 2 , supra note 51, at 448-449): Bobrishchev-Pushkin, supra note 46, at 583. See Palausov, supra note 61 at $52-59$ for a detailed analysis of how the French moved from the notion of restricting jurors to naked factual question to deciding guilt thereby leaving only the question of sentence to the professional bench. He also gives an excellent analysis of the early German theoreticians in showing professional bench. He also gives an excellent

72. $\rightarrow 760$ UUS, supra note 19, at 169 , reads: Aln cases decided with the participation of jurors, the questions posed them shall be formulated in commonly used expressions as to the substantive elements of the crimes and the guilt of the defendant, and not in the terms used in the statute.: 
abstruse terms, or wordy circumlocutions was ridiculed by critics. ${ }^{73}$ The intent of the legislator was not, however, to restrict the jurors to answering questions of naked fact, but to popularize the abstruse juridical language describing the elements of the offense, not replace it. ${ }^{74}$

The Cassational Senate's use of the provision requiring phrasing of questions in understandable terms to attempt to restrict the jury to answering naked factual question and its rejection of the prevailing view of scholars in Germany and Russia, was, according to Russian scholars, not based in any solid source of statutory authority ${ }^{75}$ and served to create a "strained, even sometimes hostile relationship between jurors and judges, inasmuch as the attempt at all costs to separate questions of fact and questions of law cannot have another result than the invasion of the crown element into the region reserved to the jury. ${ }^{176}$

One of the biggest stumbling blocks of the "fact-theorist" both now and before the revolution is the statutory requirement in both statutes that the jury determine the "guilt" of the defendant and that the judge must instruct the jury as to the applicable law.

The SCRF also insists that the jury must determine guilt, having gone as far as to overturn the first death penalty judgment following a jury verdict because the court neglected to formulate a guilt question after the jury had unanimously found the defendants had brutally killed two people in separate incidents. ${ }^{77}$ Yet the SCRF has interpreted the prohibition of "other questions requiring juridical evaluation" as applying to the basic questions relating to guilt, thus effectively removing the guilt determination from the jury and arguably violating Arts. 20, 47

73. Selitrennikov, supra note 38 , at 12,53 . Selitrennikov points how the Cassational Senate in its decisions allowed the technical word "rastratil"(embezzle) to be replaced with "izraskhodoval" (expend) or "used for his needs $\cong(379 / 1869)$. It was held further permissible to replace the phrase "openly purloinedミ "otnial." (took away) (43/69, 178/1868). "Krazha" (theft) could' be replaced with "taynoe pokhishchenie" (secret taking) and "shayka" (gang) replaced with "according to a preconceived plan with other persons engaging together in theft: $(613 / 1869)$, "s umysiom" (with intent) replaced by "zhelaia etogo" (wanting to do it) (608/1870), zavedomo (Aknowingly $\triangleq$ ) replaced with "knowing the results of his acts, understanding what he is doing.)" (1202/1872). Id. at 53.

74. Palausov, supra note 61 , at 79 .

75. Selitrennikov, supra note 38 , at 18 , notes how they could only derive it from $* 760$ UUS's requirement of using understandable terms and the general method of posing questions outlined in + 754 UUS. Palausov noted the reliance of "fact-theorists" on the provisions of +823 UUS, supra note 19 , at 177 , which provided that The defendant and his defender do not have the right to deny the credibility of the acts found proved by the jury, but may only show that these acts are not prohibited by law." This reliance was misplaced, however, for it was meant only to apply when jurors qualified their answers to the principal questions. Palausov, supra note 61, at 83.

76. Foynitskiy, Vol. III, supra note 51, quotation from reissue of the same book (1996), at 451 . (7.12.94)

77. Case of Panchishkin/Filippov (Rostov Regional Court), SCRF No. 41-kp-094-3-sk sp of the Const. RF, 78 The SCRF's decision also seems to contradict 9451 (para.3) UPK RSFSR which requires the presiding judge in his/her summation to, inter alia, "introduce the content of the accusatory pleading; explain the content of the criminal statute which provides for responsibility for the commission of the crime of which defendant is charged. "Pre-revolutionary law provided for a similarly detailed explication of the law to the jurors. ${ }^{79}$ The senselessness of such provisions if the jury is not responsible for applying the law to the facts was pointed out by legal scholars in criticizing the practice of the Cassational Senate before the Revolution. ${ }^{80}$

The confusion caused by the SCRF's interpretation becomes clear, when one compares the three basic questions to be answered by the jury per +449 UPK RSFSR, with the questions to be answered by a single judge, or a court with lay assessors. In reaching its judgment, the non-jury court must answer the following questions:

1. "did the act take place for which the accused has been accused

2. does the act contain the elements of a crime and according to which section of the criminal code;

3. did the defendant commit the act;

4. is the defendant guilty of committing the crime. ${ }^{81}$

The question as to whether the act for which defendant has been accused in the indictment contains the elements of a crime ${ }^{82}$ must be answered in the affirmative by the trial judge at the preliminary hearing in both jury and non-jury trials for there even to be a trial in the first place. ${ }^{83}$ Clearly, the second question in * 303 UPK RSFSR must be answered before questions 3 and 4 , and if answered in the negative, the answers to 3 and 4 become irrelevant. Thus, the division of labor in jury cases has been to allocate the guilt question to the jury and, the rest of the questions, i.e., whether defendant should be sentenced, the magnitude of

78. Art. 20 Const. RF, grants criminal defendants the right to trial by jury when threatened with capital punishment; Art 47 Const. RF, grants criminal defendants the right to trial by jury to the extent provided by law.

79. 3801 UUS (note 18, supra), at 174: "In cases heard with a jury, the presiding judge, at the time of handing the foreperson the question list, explains them: (1) the substantive circumstances of the case and the laws relating to determining the character of the felony or misdemeanor before the court, and (2) the general juridical basis for judgment of the strength of the evidence introduced in favor of and against the defendant

80. Foynitskiy, Vol. 2, supra note 51 , at $448-449$. Selitrennikov, supra note 38 , at 29-30, noted: "Why, after all, all this long part of the speech about laws, about their true meaning, when the discussion of the facts from the point of view of the law is forbidden fruit for the jurors? "

81. + 303 (paras. I-5) UPK RSFSR

82. $+303(2)$ UPK RSFSR.

83. $\div 433,5(2), 221,222$ UPK RSFSR. 
the sentence, resolution of the civil suit, etc., 84 to the professional judge.
Palausov 85 makes this argument in relation to the prerevolutionary law claiming Palauso ${ }^{85}$ makes this argument in relation to the pre-revolutionary law, claiming that the meaning of "guilt" cannot be different if decided by jurors, than if decided by a court without jury. Although the judge is required to determine the "juridical consequences of the jury's verdict, including questions of the qualification of the act committed by the defendant," 86 following the verdict, it can scarcely be argued that the statute intended to transpose the answering of the question as to whether the acts of the defendant constituted a crime in all cases to a time after the jury has decided guilt. For there is no guilt if there is no crime. It is incumbent on the trial judge to formulate the three basic questions so that they necessarily contain all required elements of the charged crime(s) ${ }^{87}$ and that the jury knows, following the summation or from the tharged jury knows, following questions as posed in the affirmative they a themselves, that by answering the charged crimes, or lesser includive they are convicting the defendant of the upon to "qualify" the verdict if, as happenses. The judge would only be called upon to "qualify" the verdict if, as happened both before the revolution, and in questions, or fian jury trials, the jury crosses out or changes the text of the basic questions, or finds the aggravating circumstance not to have been proved, etc

\section{b. Treatment of Aggravating Circumstances in Modern Russian Jurisprudence}

The SCRF's dogma limiting the competence of the jury is critically important when it comes to the aggravating circumstances that turn an intentional killing into capital murder and the possible imposition of the turn an intentional killing into capital murder and the possible imposition of the death penalty. This can first be aggraving examing how questions relating to two of the most common aggravating circumstances in modern Russian capital murder casēs have been handled, those of "hooliganistic motivation" and "exceptional cruelty."89 In the first year of jury trials, the majority of judges formulated the questions relative to these

84. * $303(5-10)$ UPK RSFSR

85. Palausov, supra note 61 , at 95-97.

86* 458 UPK RSFSR

87. Foynitskiy, Vol. 2, supra note 51 , at 456

88.- Selitrennikov, supra note 38, at 20. Compare this with the old English juries drafting of narrative verdicts totally contrary to the facts in order to save an accused murderer's life. Green, supra note 13 , at $28-64$. In a recent case the jury was asked to answer whether it had been Gren, supra multitude of blows with a metal instrument, hands and feet were inflicted on Klochlowa croved that injuries listed in the question, which led to her death, all in the attic Kochkova causing bodily Ogorodnaia in Saratov. The jury answered: "Yes, proved, with the exception of the acts in $200 \mathrm{UI}$ They thus changed the formulation of the question. The SCRF reversed the acts in the attic. claiming the jury, in changing the place of the commission of the crime Awe ensuing acquitta the trials and there act was tantamount to amending the crime, Awent beyond the limits of (Saratov Regional Count) SCRF No. 32 kp to amending the accusatory pleading. Case of Poliako

89. $\rightarrow 102(b, g)$ UK RSFSR, currently $\rightarrow 105(2)(d, i)$ UKRF aggravating circumstances so as to allow the jury to either directly or indirectiy decide whether the conduct of the defendant fell within the statutory definition. In some cases the jury was first asked whether it had been proved that defendan committed the charged homicides, listing the precise acts perpetrated and injuries inflicted, and then whether the murder was committed out of "hooliganistic motivation" or with "exceptional cruelty." The definitions of these crimes, usually drawn from opinions of the Supreme Court or UPK commentaries, were then read to the jury during the judge's summation. ${ }^{90}$ Other judges allowed the jury to indirectly determine the aggravating circumstances by formulating the questions in cases of "hooliganistic motivation" in relation to the alleged lack of motive (or insignificant one), which accompanied the killing. For example: "Has it been proved, that Kashuba committed the above-described acts (including shooting the victim to death) in the absence of any provocation from Vorozhet or his friends?"1 Or: "Has it been proved, that Brazhin killed the victims using the insignificant reason of their just demands that he leave their apartment (after he had broken in in order to drink vodka)?" 92 In cases of alleged exceptional cruelty, questions were asked in relation to whether the defendant, in inflicting the bodily injuries which led to the victim's death, harbored the intent to "inflict exceptional pain and suffering" on the victim. Finally, other judges have held that the jury must answer only factual questions related to the precise manner in which a murder was committed, and it is for the judge to decide whether it was a murder out of hooliganistic motivation or with exceptional cruelty. For instance: "Is Bortsov guilty, that on May 23, 1993 at about midnight near the cultural palace "Peace" in the city of Saratov, following Zakopaylo's refusal to engage in sexual intercourse with him, he dealt her a multitude of blows with his hands and feet and with an empty bottle on different parts of her body, crushed the organs in her neck, hit her with a wooden object in the area of her eyes, with the intent to kill her, causing the bodily injuries described in Question I, which led to the death of Zakopaylo? Upon an affirmative answer, the judge decided that fact situation constituted exceptional cruelty, but not hooliganistic motivation. ${ }^{93}$

90. According to an opinion of the Plenum of the USSR Supreme Court of 9.22 .89 , Murder out of hooliganistic motivation is accompanied by a "clear lack of respect for society, a gross violation of the rules of collective living and morality. "They are killings out of mischief, foolhardiness, daring, or as a response to insignificant affronts. Cited in Thaman, Resurrection, supra note 16, at 104 (note 267).

91. Case of Kashuba/Bykov (Saratov Regional Court)(Judgment 7.8.94).

92. Case of Brazhin (Saratov Regional Court) (Judgment 8.3.94).

93. Case of Bortsoy (Saratov Regional Court) (Judgment 2.18.94). In detail, see Thaman, Resurrection, supra note 16, at 120-121. 
As we have seen, the SCRF in its Dec. No. $9,+18^{94}$ has taken the decision as to these death-penalty-triggering aggravating circumstances away from the jury by restricting them to the ascertainment of "naked facts, "i.e., the amount of wounds inflicted, the lack of motive, etc., without letting them decide the "guilt" of the aggravating factor so vital to the interests of the defendant. One asks whether this is not a violation of Art. 20 Const. RF, depriving the defendant of the right to have a jury decide guilt in capital murder cases. ${ }^{95}$

\section{c. Treatment of mens rea in Russian Question Lists}

An immutable tenet of the criminal law, accepted in all Common Law or civil law jurisdictions, is that actus not facit reum nisi mens sit rea (an act does not make one guilly unless his mind is guilty) ${ }^{96}$ Thus, the definition of any criminal offense must include the prohibited acts (actus reus) or omissions, and the mental state or mens rea which makes the acts criminal. The Model Penal Code has tried to harmonize the sometimes archaic and confused descriptions of mental state in the Common Law and settled on four classic types of mens rea which will make an act criminal: purposiveness (intentionality); knowledge (of the nature of one's acts or of the existence of attendant circumstances); recklessness (consciousness of a risk); and negligence (failure to appreciate a risk). ${ }^{97}$ These mental states are also typical in Continental European descriptions of criminal offenses.

Under the Jury Law of 1864, the jury was explicitly instructed that they were to decide the required mental state of the defendant in reachifig their guilt decision. +811 UUS, which guided the judge in instructing the jury, provided as follows:

"The decision as to each question should consist in an affirmative "yes" or a negative " 0 " , coupled with that word, which contains the substance of the answer. Thus, as to the questions: "Was the crime committed? is the defendant guilty thereof? Did he act with premeditation? ", the affirmative answers should be: "Yes, it was committed-Yes, guilty, -Yes, with premeditation" 98

94. See supra text accompanying note 24

95. I have made this argument in Thaman, Postanovka, supra note 44, at 11

96. WAYNe R. LAFAVE \& AUSTIN W. SCOTT, JR. CRIMINAL LAW (2d Ed.) (1986), at 212

97. Id. at 214.

98. $\rightarrow 811$ UUS, supra note 19 , at 175

\section{Furthermore, \& 812 UUS provided:}

"When the jurors assert, that it is impossible to express with exactitude their opinion with a mere affirmation or negation, they may give the appropriate meaning to their answer by adding some words to the established expression, for instance: > Yes, guilty, but without premeditation.' "g9

Despite the apparent clarity of the law, ${ }^{100}$ the Cassational Senate in some of its rulings held that the question list only had to include a narrative describing the external facts of the charged crime and did not have to lay out the mental element for the jury to decide. The Court could then find the charged crime or lesserinciuded offenses based on the jury's answers. ${ }^{101}$ Critics, among them Palausov, harshly criticized the ambivalerice of the court of cassation, and maintained that the question of guilt had to include that of imputability, and, if it did not, the questions submitted to the jury would Aexclude even the concept of a criminal offense in a legal sense. $\cong^{102}$ Selitrennikov provides what he deems to be a proper formulation of questions in a case involving a defense of insanity, which was also approved by the Cassational Senate:

"(1) Was the violent killing of Ivan Grigorev committed by a person close to him on June 11, 1869 in the city of Rostov in the cottage of the peasant Advota Fedorova, and, to wit, by his wife, Matrena Trofimova, who was at this time 17 years, 2 months and 24 days old? (2) If it was committed, has it been proved that the defendant Matrena Trofimova was, at the time of the commission of the aforementioned crime, in the throes of an illness, which led her to delirium or to complete unconsciousness? (3) If it has not been proved, then is the defendant Matrena Trofinova guilty of the crime mentioned in the first question? (4) If she is guilty, was the crime committed by her with premeditation? 103

Bobrishchev-Pushkin provides another example of how pre-revolutionary juries directly answered questions dealing with intent and sanity, which is drawn from the Case of Vladimirov, which he prosecuted in 1882. The defendant had contended that he strangled Stepanov in a forest near Novgorod when both he and the victim were drunk, and only after voices had told him to do so. Bobrishchev-Pushkin moved to dismiss the case because he felt he could not prove intent, but the motion was denied. The jury answered the three main

\section{9. $\rightarrow 812$ UUS, ld. at 175 .}

100. Selitrennikov, supra note 38 , at 26 , felt these sections conclusively proved that jurors were meant to decide criminal intent.

101. 1d. at 77.

102. Palausov, supra note 61 at 112 . in his opinion the jury should decide questions of insanity, self-defense, and also questions as to carelessness or intent.

103. Selitrennikov, supra note 38 , at 259 , quoting Decision $488 / 1870$. 
questions as follows: "(1) Yes, Stepanov was strangled to death by Vladimirov; (2) Vladimirov was not in an abnormal condition; (3) Vladimirov is guilty, but without intent. "104

The fact that pre-revolutionary Russian jurors answered questions of mens rea does not mean they did not struggle with them, as do all jurors especially in complicated murder cases where the question of mental state can mean the difference between a possible death penalty, a conviction for manslaughter or even an acquittal due to insanity or necessary defense. Bobrishchev-Pushkin emphasized the special problems juries had when they were instructed that intent to kill could be imputed from the fact of, say, a number of stab wounds in the area of vital organs of the victim, yet the victim testified that he or she did not intend to kill. ${ }^{105}$ Jurors would often find a lack of intent due to drunkenness, especially in the context of domestic violence clouded by jealousy or anger. 106 It must also be remembered that the Cassational Panel often only required the judges to restate the mental elements for the jury in non-juridical language, but did not hold that the jury had no authority to decide such questions. ${ }^{107}$

Quite early in its jurisprudence, the Cassational Panel of the SCRF began not only treating the mental elements of crimes as "questions of law, "108 but also held that they were solely within the competence of the professional judge to decide as "questions requiring strictly juridical evaluation" in the terms of * 449(4) UPK RSFSR. This jurisprudence, which was made binding on the courts in Decision

104. Bobrishchev-Pushkin, supra note 46 , at $328-329$. The question of insanity was explicitly excluded from the competence of the jury in the 1993 Jury Law. If the question of insanity arises, the judge is to discharge the jury and institute psychiatric commitment proceedings. $э 3461(2), 403-414$ UPK RSFSR.

105. Bobrischev-Pushkin, supra note 46 , at 543. Spanish jurors in the first modern Spanish jury trials struggled with precisely the same issue, especially when the judge did not give them the option of basing murder on a theory of recklessness. See Thaman, Spain, supra note 45, at 394

106. In the Case of Filimonov ( 1880 in St. Petersburg), the jury answered that the 21 year-old

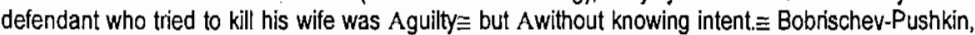
supra note 46 , at 355-356.

197. The Cassational Senate approved of the following questions: (1) Als the defendant guilty of the fact, that on January 13,1871, with another, having earlier thought about killing Ivan Chervelikov, called him to his house, where he strangled him with a cord? (1511/1872) and (2) Als Karp Semenov gully or the fact that, hi1 wing eamied $h$ intent to fulfillment on June 9,1871 , inflicting a deadly blow to his head? (974/1872), cited in
Selitrennikov, supra note 38 , at 193 .

108. See Thaman, Resurrection, supra note 16 , at 122 , Interestingly enough, prerevolutionary writers also treated questions of sanity arid intent as "serious questions of law" but never doubted that they were for the jury to decide. Bobrishchev-Pushkin, supra note 46, at 338 . They are clearly treated as questions of fact for the jury in the U.S. and are called Ainternal fact elements $\cong$ in Germany.
No. 9 of the SCRF109 has been used by the Cassational Panel to reverse number of acquittals and judgments of conviction for lesser-included crimes of homicide, often when the jury has found the defendant did not harbor the intent to kill ${ }^{110}$ or killed in the heat of passion. ${ }^{111}$

In a Moscow Regional Court case two men were tried for attempted murder in the beating of another man. The jury acquitted one defendant and found the other guilty only of inflicting minor bodily injuries without intent to kill. The convicted defendant unwisely appealed and the Cassational Panel of the SCRF on its own motion (the public prosecutor did not appear to argue the case) reversed the conviction and the acquittal, holding that the issue of intent to kill was a legal question for the judge, and send the case back for a retrial for attempted murder.. The trial judge in the second trial refused to submit the issue of intent to kill to the jury and the jury found them guilty of inflicting the yarious non-deadly wounds in a beating. The trial judge then entered judgment for attempted murder. When the jury heard this they were outraged and complained that this was not what they thought they were answering with their verdict. Defense counsel will soon bring this case to the SCRF on appeal for the second time and are considering taking the issue of intent to kill to the Constitutional Court, if the SCRF does not change its jurisprudence, and claim that it constitutes a violation of Arts. 20, 47 of the Const. RF by not allowing the jury to decide the crucial mental elements of capital offenses. ${ }^{112}$

\section{The Question of Jury Nullification}

The "sphinxlike" general verdict of "guilty" or "not guilty" in American and" British jury trials and the non-appealability of acquittals, enables juries to sometimes render a verdict contrary to the facts and the law. But it must be remembered that juries are by and large not instructed as to their power to nullify the law. The trifurcation of the guilt question in Russian special jury verdicts was criticized by Foynitskiy as being French legalistic casuistry, rejected by Germany, which allowed the jury to acquit even when all elements of the crime were

109. Supra note 24

110. Case of Somomatov/Khanitonov (Moscow Regional Court), SCRF No.4-kp-096-28sp (3.20.96), reversing a guilty verdict for inflicting injuries without intent to kill resulting in death $(+108$ UK RSFSR).

111. Case of Khachaturov (Stavropol Territorial Court). SCRF No. 19-kp-096-23sp (4.11.96); Case of Kuz'kin (Moscow Regional Court). SCRF No. 4-kp-095-114sp (10.18.95); Case of Shayko (Ulianovsk Regional Court). SCRF No. 80-kp-096-33sp (9.24.96). All were convicted of 3104 UK RSFSR (homicide in the heat of passion) and all convictions were reversed. The jury in the Shayko Case had held that defendant had killed her husband $\forall$ probably in a condition of a sudden heat of passion or emotional stress, resulting from the serious insult from the victim. "

112. Conversation with Defense Counsel Ye. Yu. L'vova, August 13, 1998, in Moscow. 
proved.113 Such so-called "jury nullification," which made the acquittal of Vera Zasulich in 1878 possible, was welcomed, however, by the judge in that case, A.F. Koni:

"Jurors are asked not whether defendant committed the criminal act, but whether he is guilty of having committed it; not the fact, but the inner aspect thereof and the personality of the defendant expressed therein, is for their decision. With its question as to guilt, the court establishes a general gap between fact and guilt and requests that the jury, based exclusively on the "conviction of its conscience" and mindful of its great moral responsibility, bridges this gap with considerations, that determine whether the defendant is guilty or not-guilty." 114

This broad approach to the jury's guilt decision is seconded by BobrishchevPushkin who saw juries as "self-proclaimed legislators" and their verdict as "social facts" which should be considered by the actual legislators in revising outdated and unpopular laws. He wrote that the

"...content of the word "guilty" in the verdict of the jury, embraces such a countless quantity of aspects of the offense, particularities in the personality of the defendant, shades of the manifestations of his will, utilitarian and ethical considerations, which can possibly be contained in each separate case, that it can never be rendered precise either by the law, by morals or by a complete juridical understanding. " 115

Russian juries before the Revolution would exercise the power of so-called "nullification" typically in the following situations: (1) to prevent the enforcement of

113. Foynitskiy Vol. 2, supra note 51 , at 454-5. Foynitskiy was not in favor of recognizing the jury $=s$ power to nulity and was a proponent of amending the laws to prevent the influence of Apublic opinion $\equiv$ in the jury's guilt decisions. Foynitskiy Vol l, supra note 42 , cited from reissue (1996) supra note 76, at 360-361. He cites for opinions of the Cassational Senate from 1904/1905 which held the the presiding judge had hat he presing jull He hed to instuct (he included the necessary elements of the crime. Id. at 452 (note 1). The new Spanish jury law avoids these problems by declaring that such a verdict is legally contradictory and in such a case the judge would have to return the jury to the jury room to correct the inconsistency. Thaman, Spain, supra note 45, at 377-378. The Cassational Senate had held that reasons for negating guilt were normally the classic excuses or justifications of the criminal law: insanity, unconsciousness, mistake, deception or self-defense. Opinion 1638/1871, cited in Selitrennikov, supra note 38, at 254.

114. Koni, supra note 30 , Vol 4 at $20 \mathrm{l}$.

115. Bobrishchev-Pushkin, supra note 46, at 38-39. Junies would Adetermine whether the act of the defendant was an evil which must be punished as a dangerous or immoral act or just something prohibited by law. If this question is difficult or too controversial they either acquit, or limit themselves to an exact establishment of factual detais in their answers, leaving the decision uniustly formulating the juridical consequences of the verdict id at 380 . unpopular laws; (2) to apply popular social notions as to the relative seriousness of certain conduct which differed from those expressed in the criminal law; (3) to prevent the imposition of what they viewed to be excessively severe sentences (4) to correct for injustices in the administration of criminal justice which were sometimes unrelated to guilt or innocence; and (5) for reasons of social custom completely unrelated to the facts of the case.

\section{a. The Nullification of Unpopular Laws}

Just as colonial American juries nullified the effect of British tax, customs and seditious libel laws, Russian juries refused to enforce the repressive passport laws. ${ }^{116}$ Juries also often refused to convict in minor cases of bribery or public corruption, because they saw the entire system as corrupt and kfren it was difficult to be honest in such a system. ${ }^{117}$ Acquittals were also often forthcoming in cases of passing forged money, because the jury viewed the defendant as himself being a victim, as having paid good money for bad, and that he was only trying to break even. ${ }^{118}$

The authors of the 1993 Russian Jury Law were aware that they were facilitating jury nullification by adopting the trifurcation of the guilt question from the 1864 law. ${ }^{119}$ The main author of the 1993 law, S.A. Pashin, recently gave a gloss on the modern Russian interpretation of a finding of "not-guilty" after finding that the defendant had committed the charged criminal acts in the first two parts of the guilt question:

"the act contains all the elements of the crime in its totality, but the jury, for reasons known to them, deprived the state of the right to achieve a conviction and apply the sanctions of the special part of the Penal Code. ${ }^{120}$

116. N.P. TIMOFEEV. SUD PRISIAZHNYKH V. ROSSII. SUDEBNYE OCHERKI. (1881), at 278-279. It was almost impossible for simple people to get a passport, and violations of the laws were punished with loss of all civil nights and long mandatory imprisonment, ibid.

117. Bobrischev-Pushkin, supra note 46 , at 291. Modern Russian juries likely have the same attitude. The defendants in the only two bribery cases tried by jury in the first year of the new Russian jury system were both acquitted. Case of Shcherbakov (Moscow Regional Court). Judgment of 4.22.94 (Thaman, Resurrection, supra note 16, at 182-183; Case of Yes'kov (Altay Territorial Court). Judgment of 7.1.94, Id. at 152-153.

118. Bobrishchev-Pushkin, supra note 46, at 292-294. In the first year of modern Russian jury trials, two of the six trials for passing counterfeit money ended in acquittals, one in a conviction for a lesser-offense, and the jury recommended special lenience in the remaining three, in which there were convictions. Thaman, Resurrection, supra note 16, at 137-138.

119. Id. at 115

120. S.A. Pashin, Postanovka voprosov pered kollegiey prisiazhnykh zasedateley, in S.A. PASHIN \& L.M. KaRNOZOVA (ed.) SOSTIAZATEL'NOE PRAVOSUDIE (1996), Vol. i, at 90-91. 
b. Nullification Due to Social Attitudes Contrary to the Principles of the Criminal Law

The following description of the relation of drunkenness to criminality in Tsarist Russia could just as well apply to the social situation in today's Russian Federation:

"The question of the extraordinary use of alcoholic beverages represents one of the most serious social questions. Drunkenness as a vice in many cases in its most ruinous manifestation, is among other things reflected in a great mass of different kinds of crimes committed primarily by simple people exclusively under the influence of their non-sober condition. Whoever has watched jury trials cannot but be struck by the huge number of cases in which drunkenness, a non-sober condition, reckless holiday drinking sprees and different gross instincts arising due to the extravagant consumption of vodka, are the main, and sometimes the direct factors in the commission of the crime. "121

Due to its connection with so much crime, Russian law has traditionally considered drunkenness to be an aggravating factor in the imposition of sentence.122 But Tsarist juries viewed drunkenness at the moment of the commission of a crime in an entirely different way than did the Old Russian Penal Code. ${ }^{123}$ Russian juries were aware that excessive consumption of alcohol could affect volition and consciousness, and therefore negate the mental states necessary for the the commission of certain crimes and they often tried to gauge how much had been drunk and to determine if it was sufficient to diminish the defendant's criminal responsibility. ${ }^{124}$

In the first year of modern Russian jury trials, the aggravating factor of drunkenness was alleged as to 89 defendants in 76 of the first 1.09 trials to go to

121. Timofeev, supra note 116 , at 380 . Bobrishchev-Pushkin, supra note 46 , at 577 , also notes the "overwhelming and specific meaning of drunkenness in Russian life."

122. In Tsarist Russia it was an aggravating circumstance if it could be shown that the defendant drank liquor to summon up courage to commit a crime. Timoleev, supra note 116 at 381. Fomser $339 / 10)$ of the UK RSFSR made drunkenness an aggravating circlimstance in all cases. This provision was eliminated from the new UK RF, enacted in 1995.

123. Id. at 381 . Bobrishchev-Pushkin, supra note 46 , at 355-356.

124. Timofeev, supra note 116 , at 382 . Timofeev, a prosecutor, recalled a case in which the jury acquitted the defendant of mayhem and answered: ANo, not guilty, and rot guilty, because he was not in a human shape. $\equiv$ (ne v chelovecheskom obraze). Id. at 383. Bobrishchev-Pushkin, another prosecutor, also noted that drunkenness often led to juries not finding criminal intent in crimes of passion, but seldom in crimes of theft, unless the victim of the theft was also drunk. BobrishchevPushkin, supra note 46, at 35, 577-579. verdict. In 47 cases the defendants were convicted of lesser-included offenses or granted lenience. ${ }^{125}$

Cases in which battered and abused wives attacked their husbands have also been typically ones in which the jury has nullified or softened the law. In the Case of Kraskina, a 1995 case out of Ivanovo Regional Court, the jury answered the three crucial guilt questions in the following manner:

"(1) Was it proved, that on October 17, 1994, at around 4:00 p.m. in apartment No. 1, at 8, UI. Ul'ianova, in the city of Navoloki, Kineshemskiy Rayon, the victim Yuriy Anatol'evich Smirnov was caused serious bodily injury in the form of a knife-wound to the brain, complicated by spinal shock, which caused his death in a short time, in minutes? (Yes, proved, unanimous).

"(2) In the event of an affirmative answer to the first question, was it proved that the above wounds were administered to the victim, who was in a serious state of alcoholic intoxication, by the defendant V.A. Kraskina, who threw him to the ground and intentionally stabbed him once with a homemade knife, which she prepared specially for this purpose, having been dissatisfied with the conduct of her companion, who had expressed in a drunken stupor profanity, and extorted money to buy alcohol? (Yes, proved, unanimous);

" (3) In the event of an affirmative answer to the second question, is V.A. Kraskina guilty of the intentional infliction of the above bodily injuries on $\mathrm{Yu}$. A. Smirnov, intending or knowingly allowing him to die? (No, not guilty, unanimous)."

This ciear acquittal of a battered woman, through the exercise of jury nullification (no legal justifications or excuses were offered in her defense), was upheld by the Cassational Panel of the Supreme Court on appeal in an opinion which upheld the jury $=\mathrm{s}$ right to nullify the law. ${ }^{126}$

Although Tsarist juries usually did not acquit a woman when she killed her husband while sleeping, in the Case of Kuz'mina, the jury found a peasant woman

125: Thaman, uury as Catalyst, supra note (note 64 , supra); at 405 (fn. 85).

126. Case of Kraskina (Ivanovo Regional Court). Judgment 7.20.95. Cited in LETOPIs' SUDA PRISIAZHNYKH. (State Legal Department of the President of the RF). Vol. 5. Moscow. 1995, at 20-21. Cf. Mikhail Ovcharov. Sud prisiazhnykh reshil: knoroshego muzha zhena ubivat' ne stanet. IZVESTIIA. 7.21.95, at 6 . Another alleged battered woman did not fare so well; howver. In the retrial of the Case of Shayko, supra note 111, the defendant was convicted of aggravated murder after her conviction for homicide in the heat of passion of her battering husband was overturned. In the retrial, the trial judge refused to allow the deiendant to admit evidence of the bad character of her husband and his previous acts of violence, thus making a nullification or sympathy verdict more difficult The Cassational Panel refused to set aside the conviction. Case of Shayko (Ul'ianovsk Regional Court). SCRF Dec, 80-kp-097-28sp (6.3.97) 
guilty of the lesser-offense of infliction of bodily injury resulting in death without intent to kill, though she poured an entire boiling samovar onto his genitals while he was sleeping, locked the door of their hut, and let him suffer for 5 days until he died. 127

Tsarist juries would also tend to be exceedingly lenient and even acquit in cases in which the defendant gave a full judicial confession and expressed remorse before the jury. ${ }^{128}$ Such in-court conduct was often more important for the jury than the evidence of past acts presented by the prosecutori29 Timofeev noted that before 1864 , criminal investigators used all kinds of tricks to get the suspects to confess, including the use of priests, but after the introduction of trial by jury defendants veritably threw themselves at the mercy of the jury. ${ }^{130}$ Vestiges of this old Russian tradition were evident in the third trial in Ivanovo Region, witnessed by the author, in which the defendant fully admitted guilt to all the charges in the accusatory pleadings, including attempted rape and aggravated murder, but claimed he did not remember doing any of them because of his drunkenness. The jury acquitted as to all of the most serious charges, most likely because the young man had no prior criminal record, had been a model village dweller, and appeared sincere in his remorse. ${ }^{131}$

\section{c. Sanction Nullification}

Tsarist juries often acquitted because they felt the sentencing provisions of the Sentencing Code were too severe. The law tried to prevent the jury from knowing the possible punishments but the juries always included people who knew the provisions of the code. Theft by force, for instance, was punished much more severely than secret theft, yet many jurors saw the sneak thief as a more dangerous social menace. They would therefore often acquit the strong arm

127. Cited in Bobrishchev-Pushkin, supra note 46 , at 389 .

128. Id. at 207.

129. Id. at 32 .

130. Timofeev, supra note 116, at 23-24. In one judicial district 22 of 33 defendants pleaded guitty in front of the jury. 1d. at 24. One attorney claimed that 26/84 clients pleaded guilty in the first year of jury trials, 42 of 112 in the second and 59 of 106 in the third. $/ d$. at 23 . Timofeev also tells the story of a sympathetic peasant women who was on trial for trying to poison her tyrant husband Jait house la sy house lawyers told her to admit her guilt and the jury would surely acqult. She stubbornly asserted innocence and was found gully. When asked about her unwise decision, she told her fellow cellmates that she preferred exile and hard labor to her "unwanted forced labor" with her husband. Id.
at 24-25.

131. Case of Kulakov (lvanovo Regional Court). Judgment of 2.11.94. Upheld by SCRF Decision 7-kp-094-7sp (4.20.94). See Thaman, Resurrection, supra note 16, at 104-105, 159-160. robber. The same was true of burglary and theft when only something of insignificant value was stolen. ${ }^{132}$

\section{d. Nullification to Correct for Injustices in the Administration of Criminal Justice}

Juries in Tsarist Russia often acquitted in cases in which the defendant had spent a long time in pre-trial detention, due to the snail's pace of criminal investigations at the time. ${ }^{133}$ The "premature doing of time" was considered, in the eyes of the jury, to be a completely adequate basis for acquitting defendants who, under other conditions, would be found guilty. ${ }^{134}$

Attempts to make the defendant appear to be a victim of the system, despite having committed a serious crime, were certainly instrumental in the acquittal of O.J. Simpson and have been playing a considerable role in the first modern Russian jury trials, in which defendants have often claimed that their confessions of guilt during the preliminary investigation were the results or police use of coercion, threats or promises. ${ }^{135}$ Such attempts by the defense to gain sympathy with the jury, but also to explain why they confessed to crimes they claimed they did not commit have been greatly undermined by recent decisions by the Cassational Panel of the SCRF which have reversed acquittais and otherwise prodefense verdicts because the lawyer, the defendant, or witnesses have tried to convince the jury that the defendants's earlier incriminating statements had been the product of unlawful force, threats or other tactics by the investigator. ${ }^{136}$ in the

132. Timofeev, supra note 116 , at $267-271$

133. Bobrishchev-Pushkin, supra note 46 , at 207 . Juries would also acquit if they were aware that the defendant $=\mathrm{s}$ co-partner in crime had escaped punishment. Id. at 254

134. Timofeev, supra note 116 , at 387 .

135. On the allegations of coercion in the first year of modem Russian jury trials and of use of torture by Russian criminal investigators, see Thaman, Resurrection, supra note 16, at 103-104. In three of 16 prosecutions for multiple murder, juries acquitted despite the fact of a previous confession. d., at 137. For a thorough study of the problem, see CONFESSIONS AT ANY COST. POLICE TORTURE iN RusSIA (Human Rights Watch) (1999).

136. In the Case of Kornilov/Nikulenko/Gerner, a quadruple murder case, in which there was credible evidence of the defendants= innocence, the presiding judge dismissed the jury after 20 days of trial in the first case and set the case for trial again. Komilov was convicted in the second trial and sentenced to death but that sentence was reversed on appeal by the Cassational Panel on 11.30.94. In the third trial, Kornilor was acquitted, but that case was reversed due to the fact that the defense argued the coercive tactics of the investigators in getting the defendants to incriminate themselves. Case of Komilov et al (Rostov Regional Court),), acquittal of aggravated murder of four people, reversed in SCRF No. 41-kp-096-39sp (5.14.96). The defendant was again tried and acquitted and the prosecutor did not appeal See L. F. Markina iz kamery smetnikov $v$ rodit and

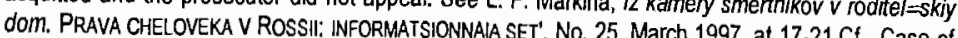
Zhevak (Rostov Regional Court) acquittal of intentior. No. 25. March 19g7, al 17-21.Cf. Case of No. 41-kp-096-24sp (4.10.96): Case of Popov (Sartenal murder and other charges, reversed, SCRF reversed, SCRF (40. reversed, SCRF No. $32 \mathrm{kp}-097-21 \mathrm{sp}$. (5.29.97); Case of Antipov (Rostov Regional Court), acquittal 
U.S., just as in Russia, the hearing to determine whether an allegedly coerced confession has been obtained in violation of the constitution is heard out of the presence of the jury. But even if the judge deems that the defense has not proven the coercive acts of the police and allows the jury to hear the confession, the defense may still argue the coercive conduct to prove to the jury that the confession is not reliable. The rulings of the Cassational Panel prevent the jury from hearing reliable evidence as to credibility of the otherwise admissible evidence, and therefore prevents a defendant from effectively arguing that there were reasons for his false confession.

This doctrine puts the defense in a difficult position in running the risk of reversal of a favorable verdict if it raises Aotherwise relevant= evidence in trying to avoid what is in many cases a possible death sentence. ${ }^{137}$ This is especially the case, inasmuch as it is well-known that Russian police and investigators still use coercive methods to gather the Atsarina of evidence $\cong$ and false confessions are probably the source of most miscarriages of justice in Russia.

The Cassational Panel of the SCRF bases its decisions to prevent testimony as to allegedly improper investigative methods which might bear on the credibility of a confession in the following way:

"When the defendant contends that illegal acts of the investigator affected the content of the evidence gathered, the proposed procedural question should be

of rape of a minor, reversed, SCRF No.41-kp-097-27sp(4.9.97): Case of Grigorev (Altay Territorial Court), SCRF No.51 kp-097-26sp (5.7.97), in which an acquittai was reversed because defendants and witnesses testifying to coercive conduct by investigators and allegedly by his first attorney in forcing him to confess; Case of Aleshin/Grachev/Kopalin (Moscow Regional Court) SCRF No. 4-kp098-94sp (6.3.98) (reversal of acquittal of aggravated murder); Case of Grafov (Moscow Regional Court) SCRF No 4-kp-098-179sp (112598)(reversal of acquittal of rape murder). Case of Kur (ever. (reversal ockultals a rape, ater we the thendan were again acquited but the SCRF fond anther reason to reversal the acquittals, an error in the question list. Case of Kurochkin/venchikowMarkelov (Krasnodar Temtional Count) SCRF No. 18-k099-3sp (1.28.99); Case of Topehiy (Krasnodar Territorial Court) SCRF No. 18-kp-098-103s (10.28.98) (reversal of acquittal of murdering his relatives); Case of Lipkin/Kurgin/Lopukhov/Yevseev/Zorin/Moskalev (Moscow Regional Court) SCRF No, 4-kp-099-9sp (2.24.99): Case of Agafonov/Makarov/Sukhoguzov/Perili'ev (Stavropol Territorial Court) SCRF No. 19-kp-099-48sp (5.5.99)(reversal of acquittal for burglary and murder); Case of Yermolaevi/Drachenko (Rostov-on-the-Don Regional Court) SCRF No. 41-kp-099-15sp (3.10.99)(reversal of acquittals for murder with exceptional cruelty). For a discussion of the Cassational Panel's decisions in this area, see Shurygin (note 65, supra), at at 6 .

137. As a result of a moratonium on the execution of the death penalty no one has been executed since August of 1996. Nevertheless. judges continued to sentence people to death and some sentences were upheld by the Cassational Panel of the SCRF. However on February 2, 1999 the Constitutional Court of the Russian Federation declared the death penalty unconstitutiona inasmuch as the Const. RF granted all defendants the right to a jury in capital cases and the jury has only as yet been introduced in nine of the subjects of the Federation. See Postanovlerie Konstitutsionnogo Suda Rossiyskoi Federatsii (Feb. 2, 1999). Slip Opinion on File with the decided exclusively by the professional judge without the participation of the jury. According to $\rightarrow 435$ UPK RSFSR the single judge decides on the admissibility or exclusion of controverted evidence in the trial. The procedural moments of interrogations of suspects and accuseds do not relate to the factual circumstances of the case and, consequently, cannot be the object of investigation by the jury." 130

The Cassational Panel's manipulation of the doctrine of the separation of questions of fact and law to exclude evidence of illegal police tactics, which juries know happen and could cause coerced false confessions, is another rather suspect way it has found to reverse acquittals and pro-defense jury verdicts. Tsarist juries did not tend to base their verdicts on extrajudicial confessions, whether it was to the victim, a witness or the police, unless it was corrobited by other evidence. And they would base verdicts on coerced confessions, which were also not uncommon then, if the admissions were corroborated by independent evidence. ${ }^{139}$

\section{e. Reasons for Nullification Unrelated to the Facts of the Case}

Simple Russian peasant juries would invariably acquit defendants in the first and fourth weeks, and in the Passion Week of the Great Fast, for these are times when they would ask forgiveness for their sins and could not be expected to convict others. ${ }^{140}$ They would also acquit on days when the dead were remembered or in August, when the winter grain was planted. At the latter time they could not have arguments or anger, or God would not deliver a good harvest. Defendants knew this and would do anything to get their cases heard in August. ${ }^{141}$ At times of extremely hot weather, when the unventilated courtrooms would sometimes reach a temperature of 40 degrees Celsius, jurors would usually acquit. In one session, four trials in one day ended in acquittals, and, after the

138. Case of Kniazev (Moscow Regional Court). SCRF Dec. 4-kp-098-17sp (2.24.98), at 2-3, which the acquittal of defendant for robben and using force against a public of ficial-was reversed The court had ruled delendant $=s$ confession admissible in a pretrial hearing and based the reversal on the testimony of the defendant and statements of counsel in closing arguments which alluded to alleged violations of the rights of the defendant during the taking of the confession. Cl. Case of Tiutin/Tiutin/Danilov/ Miridonov (Moscow Regional Court). SCRF No. 4-kp-098-66sp (4.30.98), in which all defendants were acquitted of an aggravated murder because defense lawyers, defendants and witnesses called the jury $=\mathrm{S}$ attention to alleged illegal force used against them during the investigation.

139. Bobrishchev-Pushkin, supra note 46 , at 527 .

140. Timofeev, supra note 116 , at 135

141. Id. at 136-138. 
sitting jurors were challenged by the prosecutor, 11 of 16 subsequent cases still ended in acquittal. ${ }^{142}$

\section{An Assessment of the Jurisprudence of the Cassational Panel of the Supreme Court of the Russian Federation}

What is first apparent in investigating the jurisprudence of the Cassational Panel of the SCRF is the zeal with which they reverse jury acquittals. The following statistics are informative: in 1994173 cases were tried by the jury courts in relation to 241 defendants. $18.2 \%$ ended in acquittal, in comparison to an only $1 \%$ acquittal rate in trials without juries. Yet according to the author=s investigation, of the 19 judgments reversed by the Cassational Panel, 9 were acquittals, and only one acquittal that was appealed by the public prosecutor was not overturned. ${ }^{143}$ In 1995305 cases were tried with respect to 544 defendants and the acquittal rate fell to $14.3 \%$. In 1996336 cases were tried in relation to 622 defendants and the acquittal rate rose to $19.1 \%$ (80 acquittals as to 118 defendants). The Supreme Court reversed 55 acquittals, that is, $34.2 \%$ of all that were challenged on appeal. In 1997, 419 cases were tried in the nine regions/territories as to 825 defendants. The acquittal rate rose to $22.9 \%$ (109 acquittals as to 189 defendants). The Supreme Court reversed 50 acquittals, $48.6 \%$ of all those appealed. ${ }^{144}$ Finally, in 1998,406 cases were tried in relation to 800 defendants, and the acquittal rate was $20.6 \%, 86$ cases involving 165 defendants. Acquittals were reversed by the Cassational Panel in 50 of the 86 cases in relation to 57 individuals. ${ }^{145}$

In 1997 the largest portion of the jury judgments (and especially acquiltal judgments) reversed by the Cassational Panel have been due to Aerrors $\cong$ related to violating the division of labor between judge and jury in deciding questions of fact and law, and to improper formulations in the question list-to this effect. ${ }^{146} \mathrm{In}$ 1998, however, the largest numbers of reversals have been due to improper

142. Id. at 147 .

143. Stephen C. Thaman, Geschworenengerichte in Ost und West: Die klassische Jury und das adversarische Verfahren im Strafverfahren Rußlands und Spaniens in 41 RECHT IN OST UND WEST. 73,80 (1997).

144. Spravka o praktike rassmotrenii ugolovnykh del sudami prisiazhnykh $\vee 1997$ godu. Prepared by G.P. Ivanov (March 21, 1998). Copy on file with author. The figures for 1994-1996 were from another ASpravka $=$ given the author by President of the Cassational Panel of the SCRF, A.P. Shurygin (on file with the author).

145. Spravka po rezul=tatam izucheniia prichin otmeny $i$ izmeneniia prigovorov suda prisiazhnykh, rassmotrennykh Verkhovnym Sudom Rossiyskoy Federatsii v 1998 godu (1999), at 3,6 7. Copy on file with author. (Hereafter, Spravka 1999).

146. Spravka (3.21.98), supra note 145. attempts by the defense to influence the jurors (by complaining of coercive tactics by investigators), improper exclusion of incriminating evidence, and violations of the rights of victims, all which tend to result in reverals of acquittals. ${ }^{147}$

Tsarist juries also had a high acquittal rate. In the 918 verdicts over a 14 year-periodstudied by Bobrishchev-Pushkin, 590 ended in acquittals, 96 of which were in cases where the defendant completely admitted his or her guilt. ${ }^{148}$ Timofeev found that in one regional court there were 103 acquittals (28\% of cases) over a six month period, 18 of which were due to long pretrial detention 14 due to insufficient evidence of guilt, eight due to sympathy for a defendant in bad economic straits, 12 for other reasons (youth, relationship of the defendant to the victim, restitution having been made, mental redardation, etc.). ${ }^{149}$

Though critics of the Tsarist Cassational Senate often lamented the fact that jurors had, due to the inconsistency and lack of precedential value of the appellate rulings, to deal with the facts of the case Athrough a dificult value of the impenetrable cassational fores $\simeq 150$ the Cassational Senate employed a type of harmless error analysis, which meant that every error in the question lists did not lead to reversal of acquittals. Though the Cassational Senate prohibited the utse of "juridical terms", it would not reverse a verdict: (1) if jurors were instructed clearly, and in detailed fashion, as to the meaning of the terms used in question and in the accusatory pleading; (2) if the Cassational Senate was convinced of the correctness of the answers given; (3) when the parties did not object to the questions and the jury verdict was without problem; (4) when the juridical terms had the conversation; (5) when questions containing jurdical same meaning in everyday (6) when along with juridical terms, faning juridical terms were left unanswered (6) when along with juridical terms, factual elements were included "from which the meaning of the used terms can be divined"; and (7) if the question was susceptible to being understood by everyone. ${ }^{151}$

In comparison with the pre-Revolutionary Cassational Senate, the Cassational Panel and the Plenum of the Supreme Court have gone out of their way to reverse acquittals and have in analysis. In addition, to the author analysis. In addition, to the author=s knowledge, not once has the modern Russian court of cassation cited authority for its rulings, not once made an effor to explore the wealth of pre-Revolutionary jurisprudence and scholarly writing on the subject in reaching its decisions. A nearly unavoidable conclusion of this

147. Spravka 1999 , supra note 146 , at 9

148. Bobrishchev-Pushkin, supra note 46, at 204-205. 494 of the acquittals had admissions to some of the charged conduct as well. Id.

149. Timofeev, supra note 116 , at $391-2$.

150. Bobrischev-Pushkin (note 45 , supra), at 383

151. Selitrennikov (note 37 , supra), at $12-13$ 
analysis is that the Supreme Court of the Russian Federation is acting to deprive the jury of its historic and statutorily rooted competence to determine guilt in the modern Russian jury trials and thus violating Arts. 20 and 47 of the Constitution of the Russian Federation which guarantee the right to trial by jury. The Supreme Court is acting as a political, and not a judicial institution. Its goal appears to be the fight against crime by annulling "scandalous" jury acquittals by arbitrarily looking for, or even inventing, errors in the trial courts which were not raised on appeal by the parties. In many cases reviewed by the author, the Cassational Panel, and occasionally also the Plenum of the SCRF, has reversed judgments based on errors not raised by the appellant and respondent parties. This inquisitorial mode of reviewing jury judgments arguably violates the constitutional principle of adversary procedure enshrined in Art. 123 of the Const. RF. 152

Just as in most countries in Continental Europe in the $19^{\text {th }}$ Century, the separation of questions of law and questions of fact has been a smokescreen for a battle for competence between the professional bench and lay jurors in determining the guilt and punishability of criminal defendants. With its decisions, the Supreme Court of the Russian Federation has reduced the jury to the role of determining whether certain historical facts occurred which could or could not be the basis for a criminal conviction. And when the jury nonetheless returns a special verdict which requires the trial judge to acquit, the Supreme Court has either hypertechnically construed the Jury Law and reversed on merely formal errors, or has fashioned doctrine out of whole cloth, such as that which prevents the defense from alleging coercive techniques used by the investigative authorities, which all know are all too common, and then cited this doctrine as precedent.

Sadly, the current Supreme Court is still acting as a supervisory political institution playing its part in the fight against crime as it did in Soviet times. Though many of the acquittals it has been overturning are in shockingly brutal cases, the court is regrettably compromising its reputation as a court of law by reversing them on such specious grounds.

152. This argument has been made by: P.A. Lupinskaia, Poriadok obzhalovanila, oprotestovaniia i proverki, ne vstupivshikh v zakonnuiu silu prigovorov i postanovleniy, wnesennykh $v$ usloviiakh al=ernativnoy formy sudoproizvodstva in VESTNIK SARATOVSKOY GOSLOARSTVENNOY AKADEMII PRAVA. No. 3, 1996, at 240-241; M.V. NEMYTINA. ROSSIYSKIY SUD PRISIAZHNYKH (1995), at 29; and by judge of the Cassational panel, V. Stepalin, Sudebnyy marafon s prepiatstiviami in RossiYskor YustiTsIIA. Vol. 3, 1998, 7, at 8. 